\title{
Effects of ESR1, FSHB and RBP4 genes on litter size in a Large White and a Landrace Herd*
}

\begin{abstract}
The polymorphisms of ESR1, FSHB and RBP4 genes were detected by PCR-SSCP, PCR and PCR-RFLP in a Large White and a Landrace herd in Beijing, China and the influence of ESR1, FSHB and RBP4 on litter size traits was analyzed using three models. We found polymorphisms for the three genes in Large White besides for ESR1 and RBP4 genes in Landrace. The results showed that the most genotype effects are of ESR1 among these three genes.
\end{abstract}

Key Words: pigs, ESR1, FSHB, RBP4, litter size

Zusammenfassung

Titel der Arbeit: Einfluss der Gene ESR1, FSHB und RBP4 auf die Wurfgröße bei einer Large White und Landrace Sauenherde

In einer Large White and Landraceherde in Beijing, China wurde der Polymorphismus der Gene ESR1, FSHB und RBP4 mittels PCR-SSCP, PCR und PCR-RFLP nachgewiesen. Vorliegender Beitrag untersucht den Einfluss dieser Gene auf die Wurfgröße unter Nutzung von drei statistischen Modellen. Bei der Rasse Large White wurde für alle drei Gene Polymorphismus nachgewiesen, bei der Landrace nur für die Gene ESR1 und RBP4. Der größte Genotypeneinfluss auf die Wurfgröße konnte für ESR1 nachgewiesen werden.

Schlüsselwörter: Schwein, ESR1, FSHB, RBP4, Wurfgröße

\section{Introduction}

Litter size is one of the most important production traits in pig industry (ROTHSCHILD, 1998). In recent years, because of rapid progress of molecular biology and molecular genetics, research to detect major genes or molecular markers influencing litter size had became a hotspot, and had proved some major genes or molecular markers, including the estrogen receptor 1 (ESR1) (ROTHSCHILD et al., 1996; SHORT, 1997), the follicle-stimulating hormone beta subunit (FSHB) (ZHAO et al., 1999), the prolactin receptor (PRLR) (VINCENT et al., 1998) and the retinalbinding protein 4 (RBP4) (MESSER et al., 1996; DROEGEMUELLER et al., 1999; ROTHSCHILD et al., 2000). These investigations generally employed a candidate gene approach and studied chiefly effects of individual genes controlling reproduction. But how these genes influencing reproductive traits involve interaction effects and how much the impact of each beneficial genotype is led to no positive conclusion. The purpose of this study is to provide reliable information how more genes correlate with reproductive traits by dealing with these questions.

\section{Animals}

\section{Materials and Methods}

The breeds used in this study are French Large White and Landrace, all came from the first and the second seedstock farm of Beijing Huadu Swine Breeding Company, LTD. 
Ear tissue samples of Large White (454) and Landrace (110) were collected using a centrifuge tube $(1.5 \mathrm{ml})$ with $70 \%$ ethanol, genomic DNA was obtained by phenol and chloroforms (1:1) extraction, and stored at $-20^{\circ} \mathrm{C}$.

\section{Design of PCR Primers}

Design of PCR primers of ESR1, FSHB and RBP4 was performed according to SHORT (1997), ZHAO et al. (1999), and ROTHSCHILD et al. (2000), respectively.

\section{PCR Amplifications and Genotyping Methods}

Amplification of fragments of ESR1, FSHB, and RBP4 and genotyping was performed primarily according to JIANG et al. (2000), ZHAO et al. (1999) and ROTHSCHILD et al. (2000), but systems and conditions of reaction slightly different from what were previously reported. The PCR amplification was performed using 100-500ng of genomic DNA, $2.5 \mu \mathrm{l}$ of $10 \times \mathrm{PCR}$ buffer (containing $100 \mathrm{mM}$ Tris-HCl (pH8.0), $500 \mathrm{mM} \mathrm{KCl}, 10 \mathrm{mM}$ of $\mathrm{MgCl}_{2}$ and $0.1 \%$ glutin), $200 \mu \mathrm{M}$ of each dNTP, 10pM of each primers and $2 \mathrm{U}$ of Taq DNA polymerase in a $25 \mu \mathrm{l}$ final volume (the reagents are all come from the National Laboratories for Agrobiotechnology, China Agricultural University). Condition of ESR1 was the first cycle of: $94{ }^{\circ} \mathrm{C}, 4 \mathrm{~min} ; 60{ }^{\circ} \mathrm{C}, 1 \mathrm{~min}$; $72^{\circ} \mathrm{C}$, $1 \mathrm{~min}$, followed by 35 cycles of: $94^{\circ} \mathrm{C}, 1 \mathrm{~min} ; 60^{\circ} \mathrm{C}, 1 \mathrm{~min} ; 72^{\circ} \mathrm{C}, 1 \mathrm{~min}$, then 7 min extension at $72^{\circ} \mathrm{C}$. FSHB was $94^{\circ} \mathrm{C} 5 \mathrm{~min}$, follow by 35 cycles of : $94^{\circ} \mathrm{C}$, 30s; $58^{\circ} \mathrm{C}, 30 \mathrm{~s} ; 72^{\circ} \mathrm{C}$, $30 \mathrm{~s}$, and then $7 \mathrm{~min}$ extension at $72^{\circ} \mathrm{C}$. And $\mathrm{RBP} 4$ was $94^{\circ} \mathrm{C} 5 \mathrm{~min}, 35$ cycles of $30 \mathrm{~s}$ at $94^{\circ} \mathrm{C}, 45 \mathrm{~s}$ at $56^{\circ} \mathrm{C}, 45 \mathrm{~s}$ at $72^{\circ} \mathrm{C}$, and a final $7 \mathrm{~min}$ extension at $72^{\circ} \mathrm{C}$. The PCR reactions were incubated on Gene Amp PCR system 9600/9700/2400 (Perkin Elmer).

Polymorphism of ESR1 was detected by SSCP in $14 \%$ polyacrylamide gel electrophoresis after its PCR product was denatured $10 \mathrm{~min}$ at $98^{\circ} \mathrm{C}$. FSHB was observed directly by agarose electrophoresis. The PCR product of RBP4 was digested with $1 \mathrm{U} \mathrm{MspI}$ and incubated $4 \mathrm{~h}$ at $37^{\circ} \mathrm{C}$. The digested fragments were separated by electrophoresis in a 14\% polyacrylamide gel electrophoresis (100V, 4 5h).

\section{Statistical Analysis}

Data of litter size, which included total number born (TNB) and number born alive (NBA), were collected from the breeding farms. Three linear models were established to analyse the genotype effects of ESR1, FSHB and RBP4. Fixed effects involving herd-year-seasons, parity number, genotype and their interaction effects. Breed effect was also considered in these models, but the Large White and Landrace were analysed apart because of large difference between the two breeds. The following linear models were used:

$y_{i j k l}=\mu+H Y S_{i}+P_{j}+G_{k}+e_{i j k l}$

$y_{i j k l m n}=\mu+H Y S_{i}+P_{j}+E S R 1_{k}+F S H B_{l}+R B P 4_{m}+e_{i j k l m n}$

$y_{i j k l m n}=\mu+H Y S_{i}+P_{j}+E S R 1_{k}+F S H B_{l}+R B P 4_{m}+(E S R 1 \times F S H B \times R B P 4)_{k l m}+e_{i j k l m n}$

where, $y_{i j k l,} y_{i j k l m n}$ is the observed value; $\mu$ is the population mean value; $H Y S_{i}$ is herdyear-season effects, which showed combined effects of breeding farms, years and seasons for farrowing; $P_{j}$ is parity number effects. For Landrace, it is the effects of records of all parities of a sow, and for Large White, a separate analysis was performed for the records of the first, the second and the third and above parities; $G_{k}$ is individual gene effects of ESR1, FSHB or RBP4; $E S R 1_{k}, F S H B_{l}, R B P 4_{m}$ is gene effects 
of ESR1, FSHB and RBP4, respectively; $(E S R 1 \times F S H B \times R B P 4)_{k l m}$ is interaction effects among ESR1, FSHB and RBP4 (including 2-way and 3-way interactions); $e_{i j k l,} e_{i j k l m n}$ is the random residual effect.

GLM (General Linear Models) of SAS (8.2 version) was used for processing the data owing to unbalanced data.

\section{Results}

\section{Results of genotyping of ESR1, FSHB and RBP4}

Banding patterns of ESR1 and FSHB were consistent with what were previously reported, But RBP4 was not entirely consistent with that of ROTHSCHILD et al (2000). Which can be classified into AA (190bp, 154bp and 136bp), BB (190bp, 136bp and 108bp) and AB (190bp, 154bp, 136bp and 108bp) (Fig.).

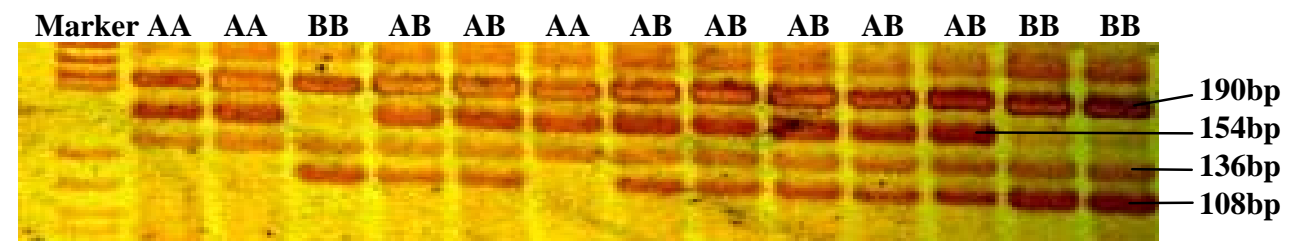

Figure: Banding patterns of RBP4

\section{Polymorphism distributions of ESR1, FSHB and RBP4}

In Landrace, the distributions of ESR1 and FSHB deviated much from each other, the A allele frequency of ESR1 was considerably higher than the other allele. On the contrary, the A allele frequency of FSHB was considerably lower than B allele, no homozygous AA animal was detected and only one heterozygous AB. The two alleles frequencies of RBP4 are close to each other (Table 1).

In Large White, the allele frequencies of ESR1 and RBP4 are also close to each other. Frequency distribution of FSHB was similar to that of Landrace, most frequent genotype is also the BB genotype. The genotype frequency distributions at every locus were all in Hardy-Weinberg equilibrium, except for ESR1 in Landrace (using a chisquare test) (Table 1$)$.

Table 1

The polymorphous distributions of ESR1, FSHB and RBP4 and HW equilibrium detection in Landrace and Large White

\begin{tabular}{|c|c|c|c|c|c|c|c|c|c|}
\hline \multirow[b]{2}{*}{ Breed } & \multirow[b]{2}{*}{ Gene } & \multicolumn{3}{|c|}{ Distribution of genotypes } & \multicolumn{2}{|c|}{ Frequencies of alleles } & \multicolumn{3}{|c|}{ H-W equilibrium detection } \\
\hline & & $\overline{\mathrm{AA}}$ & $\mathrm{BB}$ & $\overline{\mathrm{AB}}$ & $\mathrm{A}$ & $\mathrm{B}$ & $\overline{X^{2}}$ & $\mathrm{X}^{2}{ }_{0.05 \text { (2) }}$ & $\overline{\mathrm{P}}$ \\
\hline \multirow{3}{*}{ Landrace } & ESR1 & 97 & 2 & 10 & 0.9358 & 0.0642 & 239.829 & 5.99 & $\mathrm{P}<0.05$ \\
\hline & FSHB & $\mathbf{0}$ & 108 & 1 & 0.0046 & 0.9954 & 0.002 & & $\mathrm{P}>0.05$ \\
\hline & RBP4 & 34 & 20 & 53 & 0.5654 & 0.4346 & 0.007 & & $\mathrm{P}>0.05$ \\
\hline \multirow{3}{*}{ Large White } & ESR1 & 147 & 89 & 216 & 0.5642 & 0.4358 & 0.361 & 5.99 & $\mathrm{P}>0.05$ \\
\hline & FSHB & 1 & 402 & 49 & 0.0564 & 0.9436 & 0.150 & & $\mathrm{P}>0.05$ \\
\hline & RBP4 & 129 & 77 & 241 & 0.5582 & 0.4418 & 3.874 & & $\mathrm{P}>0.05$ \\
\hline
\end{tabular}

\section{Association of the ESR1, FSHB and RBP4 genotypes with litter size}

Reproductive performance of Landrace and Large White

Reproductive performances of different parities in Landrace and Large White are shown in Table 2. We have observed that mean values of TNB and NBA of parity 3 
and above were higher than the former two parities, mean values of total parities have all reached 11 piglets born and 10 piglets born alive and over, and Large White has produced nearly 1 more piglet than Landrace, it showed that reproductive performance of this study population was very well, especially of Large White.

Table 2

Reproductive performance of the different parities in Landrace and Large White (mean \pm S.D.)

\begin{tabular}{cccccccccc}
\hline Breed & Trait & $\mathrm{N}_{1}$ & Parity 1 & $\mathrm{~N}_{2}$ & Parity 2 & $\mathrm{~N}_{3}$ & Parity $\geq 3$ & $\mathrm{~N}_{\mathrm{T}}$ & Total \\
\hline \multirow{2}{*}{ Landrace } & TNB & 95 & $10.82+2.87$ & 84 & $10.62 \pm 3.35$ & 208 & $11.30 \pm 3.10$ & 387 & $11.03 \pm 3.11$ \\
& $\mathrm{NBA}$ & 92 & $10.00 \pm 2.62$ & 83 & $9.66 \pm 2.99$ & 206 & $10.16 \pm 2.86$ & 381 & $10.01 \pm 2.83$ \\
\hline Large & $\mathrm{TNB}$ & 419 & $11.65 \pm 2.86$ & 400 & $11.91 \pm 3.19$ & 1020 & $12.31 \pm 3.22$ & 1840 & $12.07 \pm 3.14$ \\
White & $\mathrm{NBA}$ & 407 & $10.66 \pm 2.59$ & 394 & $11.00 \pm 2.87$ & 1014 & $11.22 \pm 2.91$ & 1816 & $11.05 \pm 2.84$ \\
\hline
\end{tabular}

$\mathrm{N}_{1} \sim \mathrm{N}_{3}$ is litters of parity 1,2 and $\geq 3$ (including third parity); $\mathrm{N}_{\mathrm{T}}$ is total litters of all parities

Association of the ESR1, FSHB and RBP4 genotypes with litter size traits in Landrace In Landrace, we did not consider FSHB gene because of lack of polymorphism, the sample sizes are small again, and results of analysis showed the differences between different parities were not significant. Therefore, total parities were considered together. Genotype effects of ESR1, FSHB and RBP4 were analyzed with three models respectively, which were analysis of individual gene (model I), two genes included no interaction (model II) and two genes and their interaction (model III) (Table 3).

Table 3

Least squares means and standard errors for different genotypes of ESR1 and RBP4 for litter size traits with three models in Landrace

\begin{tabular}{|c|c|c|c|c|c|}
\hline Model & Gene & Genotype & Litters & TNB & NBA \\
\hline \multirow{5}{*}{ I } & & AA & 342 & $11.23 \pm 0.49$ & $9.15 \pm 0.44^{\mathrm{a}}$ \\
\hline & ESR & $\mathrm{AB}$ & 32 & $12.31 \pm 0.72$ & $10.24 \pm 0.65^{b}$ \\
\hline & \multirow{3}{*}{ RBP4 } & AA & 130 & $11.32 \pm 0.53$ & $9.27 \pm 0.48$ \\
\hline & & BB & 68 & $11.45 \pm 0.59$ & $9.22 \pm 0.54$ \\
\hline & & $\mathrm{AB}$ & 177 & $11.17 \pm 0.54$ & $9.13 \pm 0.49$ \\
\hline \multirow{5}{*}{ II } & & AA & 346 & $11.26 \pm 0.49^{\mathrm{a}}$ & $9.15 \pm 0.45^{\mathrm{a}}$ \\
\hline & ESR & $\mathrm{AB}$ & 29 & $12.55 \pm 0.75^{b}$ & $10.37 \pm 0.68^{b}$ \\
\hline & \multirow{3}{*}{ RBP4 } & AA & 130 & $11.88 \pm 0.59$ & $9.79 \pm 0.53$ \\
\hline & & BB & 68 & $12.05 \pm 0.65$ & $9.79 \pm 0.59$ \\
\hline & & $\mathrm{AB}$ & 177 & $11.79 \pm 0.61$ & $9.71 \pm 0.55$ \\
\hline \multirow{5}{*}{ III } & & AA & 346 & $11.26 \pm 0.49^{\mathrm{a}}$ & $9.14 \pm 0.45^{\mathrm{A}}$ \\
\hline & ESR & $\mathrm{AB}$ & 29 & $12.83 \pm 0.79^{b}$ & $10.75 \pm 0.71^{\mathrm{B}}$ \\
\hline & \multirow{3}{*}{ RBP4 } & AA & 130 & $12.05 \pm 0.64$ & $9.90 \pm 0.57^{\mathrm{ab}}$ \\
\hline & & BB & 68 & $12.84 \pm 0.86$ & $10.80 \pm 0.77^{\mathrm{a}}$ \\
\hline & & $\mathrm{AB}$ & 177 & $11.24 \pm 0.69$ & $9.14 \pm 0.62^{b}$ \\
\hline
\end{tabular}

Small letters (a, b) denoted significance difference $(\mathrm{P}<0.05)$; capital letters $(\mathrm{A}, \mathrm{B})$ denoted very significance difference $(\mathrm{P}<0.01)$.

The analysis result of model I indicated that least squares means of different genotypes for ESR1 had all the same trends, $\mathrm{AB}>\mathrm{AA}$, for TNB and NBA, and reached a significant level $(\mathrm{P}<0.05)$, the $\mathrm{AB}$ sows had an advantage of 1.08 pigs in TNB and of 1.9 pigs in NBA per litter across all parities over the BB sows, respectively; But no significant differences were found among the three RBP4 genotypes for litter size. 
Using model II, difference between genotypes of ESR1 for TNB and NBA all reached a significant level, the AB sows had an advantage of 1.29 piglets in TNB and of 1.22 piglets in NBA per litter over the AA sows, respectively; However, genotype effects of RBP4 did not reach a significant level.

Using model III, the sows with AB genotype of ESR1 had an advantage of 1.57 pigs in TNB and of 1.61 pigs in NBA per litter over the AA sows, respectively, and reached a significant and very significant level $(\mathrm{P}<0.01)$; The sows with $\mathrm{BB}$ genotype of RBP4 had an advantage of 1.60 pigs per litter over the $A B$, although the difference was not significant, $B B>A A>A B$, and showed the same trend in NBA, the $B B$ sows had an advantage of 1.66 pigs per litter in NBA over the AB, and reached a significant level.

Table 4

Least squares means and standard errors for different genotypes of ESR1, FSHB and RBP4 for litter size traits with three models in Large White

\begin{tabular}{|c|c|c|c|c|c|c|c|c|c|c|c|}
\hline \multirow[t]{2}{*}{ Model } & \multirow{2}{*}{ Genes } & \multirow[t]{2}{*}{ Genotypes } & \multicolumn{3}{|c|}{ Parity 1} & \multicolumn{3}{|c|}{ Parity 2} & \multicolumn{3}{|c|}{ Parity $\geq 3$} \\
\hline & & & $\mathrm{N}$ & TNB & NBA & $\mathrm{N}$ & TNB & NBA & $\mathrm{N}$ & TNB & NBA \\
\hline \multirow{8}{*}{ I } & \multirow{3}{*}{ ESR1 } & AA & 141 & $11.06 \pm 0.38$ & $10.15 \pm 0.34$ & 132 & $11.42 \pm 0.46$ & $10.27 \pm 0.41$ & 351 & $12.08 \pm 0.29^{\mathrm{a}}$ & $10.39 \pm 0.27$ \\
\hline & & $\mathrm{BB}$ & 79 & $11.37 \pm 0.47$ & $10.02 \pm 0.42$ & 73 & $11.38 \pm 0.52$ & $10.10 \pm 0.46$ & 168 & $12.34 \pm 0.36^{\mathrm{A}}$ & $10.89 \pm 0.33^{\mathrm{a}}$ \\
\hline & & $\mathrm{AB}$ & 193 & $11.20 \pm 0.39$ & $10.23 \pm 0.34$ & 191 & $11.87 \pm 0.43$ & $10.76 \pm 0.38$ & 483 & $11.55 \pm 0.29^{\mathrm{bB}}$ & $10.14 \pm 0.28^{\mathrm{b}}$ \\
\hline & & $\mathrm{BB}$ & 371 & $11.22 \pm 0.36$ & $10.20 \pm 0.32$ & 353 & $11.77 \pm 0.40$ & $10.55 \pm 0.36$ & 871 & $11.88 \pm 0.27$ & $10.34 \pm 0.26$ \\
\hline & FSHB & $\mathrm{AB}$ & 42 & $10.83 \pm 0.52$ & $10.01 \pm 0.47$ & 43 & $10.82 \pm 0.59$ & $10.02 \pm 0.54$ & 131 & $11.92 \pm 0.37$ & $10.42 \pm 0.34$ \\
\hline & \multirow{3}{*}{ RBP4 } & AA & 117 & $11.03 \pm 0.40$ & $10.06 \pm 0.36$ & 115 & $10.41 \pm 0.40$ & $11.40 \pm 0.45$ & 293 & $11.78 \pm 0.31$ & $10.31 \pm 0.29$ \\
\hline & & $\mathrm{BB}$ & 69 & $11.50 \pm 0.48$ & $10.32 \pm 0.43$ & 69 & $11.00 \pm 0.48$ & $12.16 \pm 0.54$ & 136 & $11.55 \pm 0.38$ & $10.16 \pm 0.35$ \\
\hline & & $\mathrm{AB}$ & 222 & $11.23 \pm 0.38$ & $10.16 \pm 0.34$ & 207 & $10.33 \pm 0.39$ & $11.61 \pm 0.44$ & 563 & $11.96 \pm 0.29$ & $10.36 \pm 0.27$ \\
\hline \multirow{8}{*}{ II } & \multirow{3}{*}{ ESR1 } & AA & 138 & $11.04 \pm 0.43$ & $10.12 \pm 0.39$ & 132 & $11.15 \pm 0.51$ & $10.16 \pm 0.46$ & 342 & $12.01 \pm 0.33^{\mathrm{a}}$ & $10.38 \pm 0.30$ \\
\hline & & $\mathrm{BB}$ & 79 & $11.33 \pm 0.50$ & $9.98 \pm 0.45$ & 73 & $11.11 \pm 0.56$ & $9.99 \pm 0.50$ & 168 & $12.29 \pm 0.38^{\mathrm{A}}$ & $10.88 \pm 0.35^{\mathrm{A}}$ \\
\hline & & $\mathrm{AB}$ & 190 & $11.11 \pm 0.42$ & $10.19 \pm 0.38$ & 191 & $11.54 \pm 0.47$ & $10.60 \pm 0.42$ & 479 & $11.53 \pm 0.32^{\mathrm{bB}}$ & $10.14 \pm 0.30^{\mathrm{B}}$ \\
\hline & \multirow[b]{2}{*}{ FSHB } & $\mathrm{BB}$ & 366 & $11.39 \pm 0.37$ & $10.19 \pm 0.33$ & 353 & $11.83 \pm 0.42^{\mathrm{a}}$ & $10.58 \pm 0.37$ & 861 & $11.90 \pm 0.29$ & $10.42 \pm 0.27$ \\
\hline & & $\mathrm{AB}$ & 41 & $10.94 \pm 0.54$ & $10.00 \pm 0.48$ & 43 & $10.70 \pm 0.61^{\mathrm{b}}$ & $9.91 \pm 0.55$ & 128 & $11.99 \pm 0.38$ & $10.50 \pm 0.35$ \\
\hline & \multirow{3}{*}{ RBP4 } & AA & 116 & $10.93 \pm 0.44$ & $10.01 \pm 0.39$ & 115 & $10.98 \pm 0.50$ & $10.13 \pm 0.44$ & 290 & $11.96 \pm 0.33$ & $10.50 \pm 0.31$ \\
\hline & & $\mathrm{BB}$ & 69 & $11.41 \pm 0.51$ & $10.21 \pm 0.46$ & 69 & $11.68 \pm 0.57$ & $10.61 \pm 0.51$ & 136 & $11.78 \pm 0.40$ & $10.37 \pm 0.36$ \\
\hline & & $\mathrm{AB}$ & 222 & $11.14 \pm 0.42$ & $10.07 \pm 0.38$ & 207 & $11.14 \pm 0.48$ & $10.00 \pm 0.43$ & 563 & $12.09 \pm 0.31$ & $10.51 \pm 0.29$ \\
\hline \multirow{8}{*}{ III } & \multirow{3}{*}{ ESR1 } & AA & 138 & Non-est & Non-est & 132 & Non-est & Non-est & 343 & Non-est & Non-est \\
\hline & & $\mathrm{BB}$ & 79 & $11.22 \pm 0.73$ & $9.40 \pm 0.65$ & 73 & $12.80 \pm 0.81$ & $11.54 \pm 0.75$ & 169 & $12.62 \pm 0.51^{\mathrm{a}}$ & $11.17 \pm 0.47^{\mathrm{A}}$ \\
\hline & & $\mathrm{AB}$ & 190 & $11.30 \pm 0.46$ & $10.32 \pm 0.42$ & 191 & $11.41 \pm 0.50$ & $10.44 \pm 0.44$ & 482 & $11.39 \pm 0.36^{\mathrm{b}}$ & $10.01 \pm 0.34^{\mathrm{B}}$ \\
\hline & & $\mathrm{BB}$ & 366 & $11.32 \pm 0.39$ & $10.12 \pm 0.35$ & 353 & $11.93 \pm 0.43$ & $10.70 \pm 0.38$ & 866 & $11.87 \pm 031$ & $10.42 \pm 0.30$ \\
\hline & FSHB & $\mathrm{AB}$ & 41 & Non-est & Non-est & 43 & Non-est & Non-est & 128 & Non-est & Non-est \\
\hline & \multirow{3}{*}{ RBP4 } & AA & 116 & $11.19 \pm 0.63$ & $9.96 \pm 0.56$ & 115 & $12.17 \pm 0.72$ & $11.20 \pm 0.63$ & 290 & $11 . .82 \pm 0.44$ & $10.42 \pm 0.41$ \\
\hline & & $\mathrm{BB}$ & 69 & Non-est & Non-est & 69 & Non-est & Non-est & 138 & Non-est & Non-est \\
\hline & & $A B$ & 222 & $10.49 \pm 0.48$ & $9.66 \pm 0.43$ & 207 & $11.08 \pm 0.57$ & $10.09 \pm 0.51$ & 566 & $12.18 \pm 0.36$ & $10.61 \pm 0.33$ \\
\hline
\end{tabular}

Small letters (a, b)denoted significance difference $(\mathrm{P}<0.05)$; capital letters $(\mathrm{A}, \mathrm{B})$ denoted very significance difference $(\mathrm{P}<0.01)$.

Association of the ESR1, FSHB and RBP4 genotypes with litter size traits in Large White

In Large White, the genotype effects of ESR1, FSHB and RBP4 were also analyzed with these three models respectively, but refer to these three genes different from that of Landrace. At same time, a separate analysis was performed for different parities (1, 2 and $\geq 3$ ) (Table 4). 
The analysis of individual gene (model I) showed that only the genotype effects of ESR1 of these three genes reached a significant or very significant level at parity 3 and above. For TNB, BB $>A A>A B$, the sows with $B B$ and $A A$ genotype produced 0.79 and 0.53 piglets per litter more than those of $A B$ genotype, respectively; the traits of NBA were similar to the TNB, the $\mathrm{BB}$ sows produced 0.75 piglets per litter more than those of $\mathrm{AB}$ genotype, but these differences among three genotypes were not significant. However, the genotype effects of FSHB and RBP4 were not significant.

Analysis using model II, ESR1 genotype effects for TNB and NBA were significant at parity 3 and over, $\mathrm{BB}>\mathrm{AA}>\mathrm{AB}$, the $\mathrm{BB}$ sows respectively produced 0.76 of TNB and 0.74 of NBA per litter more than those of AB; FSHB genotype effects for TNB reached a significant level at parity 2, the $\mathrm{BB}$ sows produced 1.13 piglets per litter more than those of $\mathrm{AB}$; and the RBP4 genotype effects were not significant.

Analysis using model III, effects differences between different genotypes for each gene were further widen, and the interaction effects between ESR1 and RBP4, among ESR1, FSHB and RBP4 reached a significant level at different parities (1,2 and $\geq 3$ ).

\section{Discussion}

Previous research showed that favourable alleles of ESR1, FSHB and RBP4 are B, B and A, respectively (ROTHSCHILD et al., 1996; SHORT, 1997; ZHAO et al., 1997; ROTHSCHILD et al., 2000). In this study, favourable alleles of ESR1 and FSHB consist with what were reported previous, but favourable allele of RBP4 is B instead of $\mathrm{A}$, this difference is probably result from different genotyping, which may as a result of mutation of MspI locus, but needs to further study.

Differences of the genotype effects of each gene using different models were rather large (Table 3 and Table 4). In Landrace, the genotype effects of ESR1, of more significant difference, increased according to three models. For TNB and NBA, the sows with $\mathrm{AB}$ genotype respectively produced 1.08, 1.29, 1.57 and 1.09, 1.22, 1.61 piglets per litter more than those of AA genotype. Although the genotype effects of RBP4 were obviously lower than that of ESR1, the most effects were also observed using model III, additive effect of favourable allele B was 0.40 piglets in TNB and 0.45 piglets in NBA per litter, respectively, this result is close to that of OLLIVIER et al. (1997), but over that of ROTHSCHILD et al. (2000), while the genotype effects of RBP4 were not significant in the analysis using the former two models. The trends of varieties of ESR1, FSHB and RBP4 in Large White are the same as that of Landrace. The most genotype effects of ESR1 were observed upward of parity 3 and with model III, for TNB and NBA, the sows with BB genotype respectively produced 1.23 and 1.16 piglets per litter more than those of $A B$ genotype. The genotype effects of the other two genes were not such significant, but the difference of genotype effects are also widen using model I, II and III.

The current study had confirmed that there was interaction effects among genes that are significant associated with litter size traits, which will be further discussed in the second manuscript. Therefore, the interaction effects must be considered when performing analysis of effects of multi genes on the trait.

The results of this study were showed the impact of parities on the litter size traits. No significant difference among the first six parities, but the difference is significantly between parity 7 9 and the other parities. This result disagrees with that of some researchers (CHEN et al., 2000; 2001), who usually consider that the first parity have 
more significant effect on litter size than others parities. What needs pointing out is that the data recording of this experiment were up to parity 11 , in contrast to other reports were usually no more than 7 parities on recorded. In addition, the effects of herd-year-season on the litter size traits were significant, so the effects of the parities and herd-year- season must be considered when performing statistical analysis.

\section{Acknowledgements}

The authors would like to thank Beijing Huadu Swine Breeding Company, LTD for collecting samples and Prof. Dr. Franz Pirchner for reading the manuscript.

\section{References}

CHEN, K. F.; HUANG, L.S.; LI, N.; ZHANG, Q.; LUO, M.; WU, C.X.:

The genetic effect of estrogen receptor (ESR) on the litter size traits. Acta Genetica Sinica, 27 (2000), $10,853-857$

CHEN,K.F.;HUANG,L.S.;LI,N.;ZHANG,Q.;ZHANG,J.S.;SUN,S.Q.;LUO,M.;WU,C.X.:

The combined genotypes effect of ESR and FSHßgenes on litter size traits in five different pig breeds. Chinese Science Bulletin. 46 (2001) 2, 140-143

DROEGEMUELLER, C.; HAMANN, H.; THIEVEN, U.; KRIETER, J.; DISTL, O.; HARLIZIUS, B.: Influence of the genome region surrounding the estrogen receptor (ESR) gene on litter size in a German Landrace population. Arch. Tierz., Dummerstorf 42 (1999) Special Issue, 175-177

JIANG, Y. L.; LI, N.; XI, Q.Y.; WU, C. X.:

Detection of point mutation of porcine estrogen receptor gene (ESR) by PCR-SSCP approach. Hereditas, 22 (2000) 4, 214-216

MESSER, L.A.; WANG, L.; LEGUALT, C.; ROTHSCHILD, M. F.:

Mapping and investigation of candidate genes for litter size in French large white pigs. Anim Genet. 27 (1996) Suppl. 2, 101-119

OLLIVIER, L.; MESSER, L.A.; ROTHSCHILD, M. F.; LEGAULT, C.:

The use of selection experiments for detecting quantitative trait loci with an application to the INRA hyperprolific pig. Genet. Res. 69 (1997), 227-232

ROTHSCHILD, M. F.; MESSER, L.; DAY, A.; WALES, R.; SHORT, T.; SOUTHWOOD, O.; PLASTOW, G.: Investigation of the retinol-binding protein 4 (RBP4) gene as a candidate gene for increased litter size in pigs. Mamm. Genome. 11 (2000), 75-77

ROTHSCHILD, M. F.; FACOBSON, C.:

The estrogen receptor locus is associated with a major gene influencing litter size in pigs. Natl. Acad. Sci. USA. 93 (1996), 201-205

ROTHSCHILD, M.F.:

Analysis of new candidate genes for reproduction in the pig. Plant and Animal Genome VI Conference. San Diego. USA. (1998), W61.

SHORT, T. H.:

Effect of the estrogen receptor locus on reproduction and production traits in four commercial pig lines. J. Anim. Sci. 75 (1997) 12, 3138-3142

VINCENT, A. L.; EVANS, G.; SHORT, T. H.; SOUTHWOOD, O.; PLASTOW, G. S.; TUGGLE, C. K.; ROTHSCHILD, M. F.:

The prolactin receptor gene is associated with increased litter size in pig. Proc. 6th World Congr. Genet. Appl. Anim. Prod. 27 (1998 ), 15-18

ZHAO, Y. F.; ENG; LI, N.; XIAO, L.; CAO, G. S.; CHEN, Y. Z.; ZHANG, S.; CHEN, Y. F.; WU, C. X.: An insertion fragment FSH $\beta$ subunit gene and it was associated with litter size in porcine. Science in China (Ser. C), 29 (1999) 1, 81-86

Received: 2005-04-01

Accepted: 2005-12-19

Corresponding author

Prof. Dr. AIGUO WANG (A.G. WANG)

College of Animal Science and Technology

China Agricultural University, Beijing 100094, China 